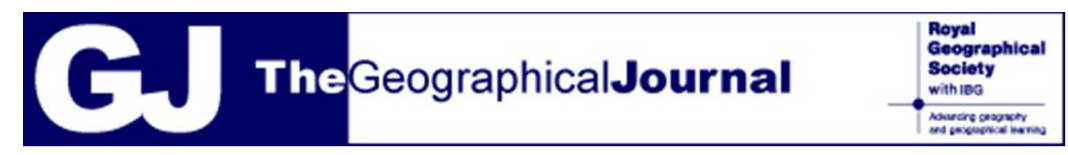

\title{
Revisiting the role of high-energy Pacific events on the environmental and cultural history of Easter Island (Rapa Nui)
}

\begin{tabular}{|c|c|}
\hline Journal: & The Geographical Journal \\
\hline Manuscript ID & GJ-RP-Jul-2017-0056.R1 \\
\hline Manuscript Type: & Regular Paper \\
\hline Keywords: & $\begin{array}{l}\text { Easter Island, Polynesian societies, Lacustrine record, Paleotsunamis, } \\
\text { Historic volcanic eruptions }\end{array}$ \\
\hline Abstract: & $\begin{array}{l}\text { Pacific islands are spread over thousands of kilometers of the Oceanic } \\
\text { Basin and are characterized by similar ecological features but very diverse } \\
\text { geologic origins, from steep volcanoes to flat coral atolls. Several climatic } \\
\text { phases have been shared among the region within the last } 1000 \text { years. } \\
\text { Numerous and abrupt societal and cultural changes during the same period } \\
\text { have been described for islands separated by thousands of kilometers. } \\
\text { Conspicuous societal changes have been exclusively attributed to the main } \\
\text { climatic patterns (changes in precipitation and temperature). The possible } \\
\text { role of tsunamis and the occurrence of large volcanic eruptions as regional } \\
\text { societal modulators, however, have traditionally received little attention } \\
\text { from archeologists, mainly due to the difficulty of recognizing them in the } \\
\text { sedimentary and geomorphological records. We explore the potential } \\
\text { influence of the most important high-energy events in the Pacific on } \\
\text { Polynesian societal changes, with a special focus on Easter Island. For } \\
\text { example, the extreme Samalas eruption in AD1257 may have been an } \\
\text { indirect driver of the sudden population decline, land degradation and } \\
\text { decreased food resources on many Pacific islands between AD1250 and } \\
1300, \text { and the Kuwae eruption in AD1450 may have triggered the } \\
\text { synchronous end of long voyaging expeditions across the Pacific. Important } \\
\text { paleotsunamis have had unquestionable impacts on coastal and seafaring } \\
\text { societies. A direct effect of the main eruptions of the last millennia } \\
\text { (AD1257 and } 1453 \text { ) on Easter Island has not yet been identified by any } \\
\text { record, but we have calculated, the likelihood of destructive tsunamis with } \\
\text { an estimated period of recurrence for large events of less than a century. } \\
\text { This insight is new and needs to be taken into account to complement what } \\
\text { we already know about Easter Island cultural history and archeological } \\
\text { sites, especially those in vulnerable coastal locations. }\end{array}$ \\
\hline
\end{tabular}




\section{Revisiting the role of high-energy Pacific events on the environmental and cultural history of Easter Island (Rapa Nui)}

Olga Margalef ${ }^{a, b}$, José A. Álvarez-Gómez ${ }^{c}$, Sergi Pla-Rabes ${ }^{a}$, Núria CañellasBoltàd, Valentí Rull $^{\mathrm{e}}$, Alberto Sáez , Adelina Geyer ${ }^{\mathrm{e}}$, Josep Peñuelas ${ }^{\mathrm{a}, \mathrm{b}}$, Jordi Sardans $^{a, b}$, Santiago Giralt $\mathbf{e}^{\mathrm{e}}$

${ }^{a}$ CREAF, 08193 Cerdanyola del Valles, Barcelona, Spain

${ }^{\mathrm{b} C S I C}$, Global Ecology Unit CREAF-CSIC-UAB, 08193 Bellaterra, Barcelona, Spain

${ }^{\mathrm{c}}$ Department of Geodynamics, Faculty of Geology, Complutense University of Madrid, 28040 Madrid, Spain

${ }^{\mathrm{d}}$ Department of History and Archaeobotany. Universitat de Barcelona. C/Montalegre 6, 08001 Barcelona, Spain

e Institute of Earth Sciences Jaume Almera (ICTJA-CSIC), C. Lluís Solé i Sabarís s/n, 08028 Barcelona, Spain

${ }^{\mathrm{f}}$ Department of Earth and Ocean Dynamics, Universitat de Barcelona, C. Martí i Franques s/n, 08028 Barcelona, Spain 


\begin{abstract}
Pacific islands are spread over thousands of kilometers of the Pacific Basin and are characterized by similar ecological features but very diverse geologic origins, from steep volcanoes to flat coral atolls. Several climatic phases have been shared among the region within the last 1000 years. Numerous and abrupt societal and cultural changes during the same period have been described for islands separated by thousands of kilometers. Conspicuous societal changes have been exclusively attributed to the main climatic patterns (changes in precipitation and temperature). The possible role of tsunamis and the occurrence of large volcanic eruptions as regional societal modulators, however, have traditionally received little attention from archeologists, mainly due to the difficulty of recognizing them in the sedimentary and geomorphological records. We explore the potential influence of the most important high-energy events in the Pacific on Polynesian societal changes, with a special focus on Easter Island. For example, the extreme Samalas eruption in AD1257 may have been an indirect driver of the sudden population decline, land degradation and decreased food resources on many Pacific islands between AD1250 and 1300, and the Kuwae eruption in AD1450 may have triggered the synchronous end of long voyaging expeditions across the Pacific. Important paleotsunamis have had unquestionable impacts on coastal and seafaring societies. A direct effect of the main eruptions of the last millennia (AD1257 and 1453) on Easter Island has not yet been identified by any record, but we have calculated, the likelihood of destructive tsunamis with an estimated period of recurrence for large events of less than a century. This insight is new and needs to be taken into account to complement what we already know about Easter Island cultural history and archeological sites, especially those in vulnerable coastal locations.
\end{abstract}




\section{INTRODUCTION}

Polynesia, Melanesia and Micronesia consist of more than 1000 islands spread over the Pacific Ocean. They define a scattered and unique landscape where native inhabitants have shared similar traits, including language, beliefs and excellent sailing skills (Figure 1). The islands are characterized by both similar ecological features but different geologic settings and topographies.

Large climatic changes have been recorded during the last millennia across the Pacific (Allen, 2006; Nunn, 2007). The Medieval Warm Period (MWP) was characterized by a rising sea level in the Pacific Basin from AD750 to 1250 and climate varied little interannually, with periods of drought along the eastern Pacific (Figure 2). The climatic shift occurred from AD1250 has been regarded as the most dramatic of the past 5000 years (Nunn, 2000, Mayeski et al., 2004, Miller 2012). This transition to the Little Ice Age (LIA) preceded the lower sea levels and cooler global temperatures that lasted until AD1750. The onset of the LIA caused large and worldwide climatic changes (Miller et al., 2012) and there are evidences of lower sea levels of up to $1.8 \mathrm{~m}$ in most parts of the Pacific Basin (Nunn and Peltier, 2001). Changes in sea level can change coastal environments and therefore resources and the shape and size of islands, especially lowlying atolls. The onset of the LIA was also characterized by a decrease in global temperature (Miller et al., 2012). Together to these climatic disruptions, the increase in storm frequency in the central Pacific (Toomey et al., 2013) has been attributed to an increase in El Niño Southern Oscillation events (cold ENSO events since circa AD1300 (Rein et al., 2004).

The changing climatic conditions between AD1250 and 1350 (the 1250-1350 period) may have caused profound societal crises. Nunn $(2000,2007)$ and Nunn et al. (2007) 
have conducted extensive interdisciplinary studies, gathering archeological, climatic and paleoecological records to explain complex societal disruption. Similar societal changes sometimes occurred on islands thousands of kilometers apart within a restricted period. The principal examples consist of (1) dietary changes, (2) sudden land degradation, (3) inland movement of coastal settlements and (4) interruption of long-distance trade among archipelagos (Figure 1). Allen (2006), however, has questioned the reliability of this wide-spread societal disruption because of the spatial climatic heterogeneity of the Pacific Ocean.

Little information, however, is available for the effects of abrupt high-energy events during the last millennia on ancient Pacific island countries (PIC) inhabitants, which is relevant due to the elevated geohazard risk of the region. The Pacific Basin is surrounded by the most tectonically active plate boundaries, the "ring of fire", the main source of earthquakes and volcanic eruptions in the world. Extremely explosive eruptions have occurred during the last 1000 years, especially in Southeast Asia, perturbing global climatic conditions and disrupting societies as distant as Europe. Tsunamis and volcanic eruptions, though, are important when studying human environmental and climatic interactions, because their effects can push former societal equilibriums to new steady states.

Archeological and paleoenvironmental studies have provided, for the moment, little information on the impacts of high-energy events on the widespread, isolated island systems. With this work, we pretend to highlight the remaining questions of the effects of volcanoes and earthquakes on old PIC societies, with a special focus on the vulnerability of Easter Island. Despite this high-energy events have been occurring in the Pacific Basin since earlier times (Goff et al., 2011), we have chosen the last 1000 years temporal window because it includes several well-known eruptions and tsunamis, 
climatic changes and many islands were already inhabited or were about to be colonized. This period represents an excellent opportunity for determining the impacts of these events on the relationship between humans and the environment.

\section{VOLCANOS: A FIRST CLIMATIC DRIVER}

\subsection{Historic eruptions in the Pacific Basin}

The Pacific Basin is surrounded by 452 volcanoes, more than $75 \%$ of the world's active volcanic systems (Simkin, 1993). Volcanic eruptions have been among the most disruptive short-term events in human history, as active triggers of global climatic and social changes (LeGrande and Anchukaitis, 2015). Some of the largest eruptions in the last 1000 years where in the Java and Tonga trenches: AD1257 (Samalas, in the island of Lombock, Indonesia), AD1453 (Kuwae), AD1665 (Long Island, Blong et al., 2017) AD1815 (Tambora) and AD1883 (Krakatoa) (Table 1). The consequences to Pacific societies of the first two are challenging to estimate, due to the additional difficulty of reconstructing history with the lack of written chronicles. However, what we know for the Tambora and Krakatoa eruptions is a good approach to infer what could happen in former eruptions. The main regional impact of the Krakatoa eruption was a tsunami that devastated the coast of the Sunda Strait and killed 40000 people (Paris et al., 2014). The injection of $3 \square 10^{13} \mathrm{~g}$ of total aerosols into the stratosphere decreased the mean global temperature by $1.2{ }^{\circ} \mathrm{C}$ (Deirmendjian, 1973) and produced unusual sunsets worldwide for the next three years (Simkin and Fiske, 1983). The Tambora eruption in 1815 was even more explosive. The effects were devastating for the surrounding islands, and thousands of people died from starvation and illness (water pollution, cholera) in the region (Oppenheimer, 2003). The massive injection of sulfate aerosols into the stratosphere led to a global cooling of $1-1.5^{\circ} \mathrm{C}$ (Self et al., 2004) with extreme impacts 
on global agricultural production (Cole Dai et al., 2009), and the worst famine throughout Europe in more than a century (Oppenheimer, 2003)..

The tropical eruption at Pinatubo in 1991 was closely monitored by the SAGE II satellite. The most optically dense portions of the cloud produced by this explosion were concentrated from $10^{\circ} \mathrm{S}$ to $30^{\circ} \mathrm{N}$ (McCormick and Veiga, 1992). Strong stratospheric winds distributed these aerosol particles widely in the following years, causing a global cooling of circa $0.5^{\circ} \mathrm{C}$ (Hansen et al., 1996).

\subsection{The Samalas AD1257 eruption}

Samalas explosion (AD1257) was the largest stratospheric volatile release during the Holocene. The sulfate concentration that reached Antarctica was nearly 4-fold higher than that of Tambora, representing an impact on the temperature of the atmosphere about 6-fold higher than the estimated anthropogenic climatic forcing since AD1750. The associated global cooling could have been 50-200\% more than from the 1991 Pinatubo eruption (LeGrande and Anchutaikis, 2015). Climatic impacts were global, e.g. heavy rains during summer and autumn throughout Europe that ruined crops, causing severe famine.

Miller et al. (2012) suggested that the Samalas eruption may have played a key role in triggering the LIA. These authors used a transient climatic model simulation to demonstrate that explosive volcanism could produce cold summers and that cooling could be maintained by sea-ice oceanic feedbacks long after the volcanic aerosols had been removed. The onset of the LIA can thus be linked to an unusual period (50 years) of large eruptions that started with the AD1257 Samalas eruption (Miller et al., 2012).

The probability of strong ENSO episodes during the cold season doubles after a large volcanic eruption at low latitudes, due to the negative shortwave surface radiative 
forcing from the injection of aerosols into the lower tropical stratosphere. Cole Dai et al. (2009) reported that the AD1257 eruption likely favored the occurrence of El Niño events in the midst of prevailing La Niña-like conditions. Consequences have been also reported in the West Pacific. Consistently, the onset of a different drainage phase at the Kuk Swamp in Papua New Guinea has been attributed to the onset of El Niño droughts after Samalas eruption (Bayliss-Smith et al., 2017).

The massive injection of aerosols into the stratosphere, however, could have had other consequences over the central Pacific, as did the Pinatubo eruption. Large ozone depletion (Schoeberl et al., 1993) allowed more UV-B to reach the ground (Self et al., 2016). The depletion at mid-latitudes (Hawaiian archipelago) reached 20\%. Moreover, pollution of the lower atmosphere with acidic aerosols could induce respiratory illness thousands of kilometers from the eruption (Self et al., 2016), groundwater contamination and serious disruption of coral growth.

The most extreme impacts of the Samalas eruption probably lasted a few years, but its occurrence during the onset of the long-term environmental changes that characterized the LIA could have had large impacts on the societal disruption described for the 12501350 period. Large areas could have been under the influence of polluted rainwater and unexpected rain patterns for years after the eruption, ruining crops and coastal resources on the Pacific islands, but also under the influence of unusually cold temperatures that could last for decades and of changes in the nature of the light due to interactions with the aerosols. The main obstacle to understanding the consequences of the Samalas eruption to Pacific populations is the lack of accurate dates for most of agricultural, dietary or settlement changes. Important changes nonetheless occurred throughout the Pacific Basin during the century after this period, whereas the influence of the Samalas eruption will need to be assessed in the future. 
Several indicators of societal disruption across the Pacific Basin between AD1250 and 1300 have been described. Sudden reduction of population occurred in Nuku Hiva (Marquesas Islands) (Weisler, 1995), and societal crises in Mangareva and the Pitcairn islands were precipitated by land degradation (Nunn, 2007). The shift from coastal to hilltop settlements was also a major indicator of societal disruption on high Pacific Islands. The consumption of marine food changed after AD1250 on other islands, such as Kapingamarangi Atoll (Federated States of Micronesia) (700 BP; Leach and Ward, 1981), Aitutaki (Cook Islands) and Guam. The populations of commensal species fell abruptly in the Marquesas Islands during the $1250-1350$ period and then partially recovered (Nunn et al., 2007). The building of megalithic monuments around the time of the 1250-1350 period represents such a short-term adaptation, in this case an appeal to a divine power. Examples are the monuments on Easter Island (Bahn and Flenley, 1992), Pohnpei in Micronesia and some Tongan islands.

\section{TSUNAMIS: THE THREAT OF THE GIANT WAVE}

The devastating effects of tsunamis have been considered as too local to be important for PICs history (Anderson, 2009). Goff et al. (2012), however, claimed that paleotsunamis have received too little attention in archeological studies because the inhabitants were coastal people and fishers that relied on boats for their trips. Recent tsunamis, such as the South Pacific Tsunami in 2009, have shown how vulnerable these islands can be (Goff et al., 2011b).

Myths that are part of the cultural heritage of PICs represent the recollections of these catastrophic events. Tales of diluvia and floods are among the most common myths in the region (Nunn and Pastorizo, 2007), e.g. the devastating tsunami recalled in Pukapuka oral traditions (Cook Islands) or the Manihiki and Rakahanga (Cook Islands) 
myth that refers to the sea as a "sheeting mass" (Gill, 1916). The coral boulders $15 \mathrm{~m}$ in diameter and weighing 1600 tonnes found $10 \mathrm{~m}$ a.s.l. in Tonga deposited by a Holocene tsunami were described by local oral tradition as giant stones thrown from the sea by the god Maui (Frohlich et al., 2009).

Tsunamis have an immense erosive power. Extreme wave events can break beach barriers, move tons of sand to infill coastal lagoons or erode an entire beach (Ramalho et al., 2013). Tsunamis typically generate boulder-strewn gravel fields with megaclasts and thin sediment accumulations in topographic lows, which can extend several hundreds of meters inland (Chagué-Goff et al., 2012). Low islands are particularly vulnerable (Woodroffe, 2008).

Well-studied of insular coastlines impacted by tsunamis include the Kohala and Kîlauea shores in Hawai'i, the northern shore of O'ahu or in the Agaete valley in Gran Canaria (Noormets et al., 2002; McMurtry et al., 2004a; Pérez-Torrado et al., 2006). Some old tsunamis have already been well described for the regions of Tahiti (Sinoto, 1979) or New Zealand (McFadgen, 2007), but most remain undiscovered. Goff et al. (2011a) proposed more than 22 possible PIC paleotsunamis from archeological, geochemical, paleoecological, geomorphological and sedimentological features. Some were equivocal and on islands where archeologists certified a sudden abandonment of coastal settlements, such as the Marquesas Islands (Aswani and Allen, 2009). Others, though, are very conclusive, such as the large paleotsunamis in Hawaii dated between 1430 and 1665. A remarkable example is the tsunami caused by the 1452-53 Kuwae eruption (Figure 1) that reached Fiji and the New Zealand coast (Goff et al., 2011a; Goff et al., 2012), or the AD1450 Tonga-Kermadec trench tsunami inferred from its affects from Pitcairn to New Zealand, separated by more than $5400 \mathrm{~km}$ (Goff et al., 2012). 
Regional open-sea voyaging rapidly collapsed in Polynesia in the $15^{\text {th }}$ century, coinciding with marked cultural changes. Accurately dating the cessation of interisland communication is difficult (Nunn et al., 2007), but the Vanuatu-Tonga trade tradition was likely suddenly interrupted in AD1450, as with the regular exchange between Henderson Island and other islands (Weisler, 1995) (Figure 2). The trade connection in eastern Polynesia among the Society Islands, Marquesas Islands and the Pitcairn group pivoted around Mangareva. The withdrawal of one of the nodes of these trading routes around AD1450 likely led to the collapse of the entire commercial tradition (Weisler, 2002). Goff et al. (2012) suggested that the coincidence of the AD1450 TongaKermadec and AD1452 Kuwae tsunamis with this interruption of inter-island trade may indicate a causal relationship. The tsunamis could have been responsible for the loss of physical assets, such as dwellings, food supplies and canoes, but also for the loss of knowledge by the death of an important segment of the population. These circumstances, together with climatic instability during the LIA, may account for the ubiquitous and long-term changes.

The incidence of tsunamis, together with other societal and environmental changes, probably forced humans to move from main coastal settlements toward inland areas and caves. The development of ridge-top settlements across the Pacific Ocean may have been partly due to the recurrence of giant waves that killed islanders and destroyed goods along the coast. Inland movements are a main characteristic of early LIA and have been described for Chuuk and Yap (Micronesia) and Kaua'i and O'ahu (Hawaii). A wholesale movement of people inland around 1450 has been described on islands within the estimated ranges of the 1450 and 1452-53 tsunamis (Goff et al., 2012), such as in Marquesas or in Lau and Viti Levu (Fiji) where the clearance of upslope vegetation indicated a communal movement (Nunn, 2007). 
The nature of this geohazard is localized in space and time. This lack of ubiquity and the difficulty of recognizing and dating the geomorphological tsunamigenic imprints are the main reasons accounting for why they have not yet been extensively studied (Anderson, 2009) and are considered as minor sources of cultural changes in the Pacific Basin. The impact of a tsunami, however, can also be catastrophic to a single island or archipelago, despite its local effect, due to the size and topography of Polynesian islands and the seafaring lifestyle. The minimum tsunami height needed to form a recognizable deposit on the coast is sometimes at least $5 \mathrm{~m}$, e.g. Cook Strait (Lowe and DeLange, 2000), but some low-lying islands can be completely inundated under waves of less than $5 \mathrm{~m}$. The remaining enigma of the mystery islands (inhabited and then abandoned) that has been associated with abandonment due to changes in sea level and water accessibility. For these islands, the hypothesis of the impact of tsunamis should be considered and contrasted with the available archeological and paleoenvironmental information.

\section{EASTER ISLAND}

Easter Island (Rapa Nui) is a small volcanic island at the easternmost edge of Polynesia and more than $3000 \mathrm{~km}$ from South America (Figure 1). Pioneer palinological studies in sedimentary lake records were conducted in the island in the early eighties, and were used to relate landscape evolution with societal and cultural changes (Flenley and King, 1984). According to their theory, the first settlers arrived between AD 800 and AD 1200 from east Polynesia and deforested the island, causing an ecological catastrophe leading to a cultural collapse (Flenley and Bahn, 2003). Another theory proposes a later arrival, between AD 1200 and AD 1300 (Wilmshurst et al., 2011). However, recent studies on lacustrine sequences revealed stratigraphic discontinuities in the sedimentation (Sáez et al., 2009) and that the first signals for anthropic disturbance occurred at $450 \mathrm{BC}$, 
associated with the appearance of a human-dispersed weed of American origin (Cañellas-Boltà et al., 2013). There is a general consensus that the island underwent important changes in landscape. However, the age and nature of deforestation has been a controversial issue. This controversy, together with latest archeological discoveries (Lipo et al.,2016) indicate that societal changes were thus transitions or transformations rather than a collapse (Rull, 2016). The need to consider the influence of climatic changes for reconstructing the evolution of the island's landscape has been recognized (Hunter-Anderson, 1998). Recent revisions have proposed holistic approaches that combine climatic, ecological and cultural changes to understand the history of the local community and landscape (Rull et al., 2016). Current revisions, however, have not incorporated the possible impact of eruptions or tsunamis on the island, despite these main ancient settlements have been found in coastal areas in Easter Island. This is, in part, because obtaining reliable records with an adequate chronology and temporal resolution for understanding the effect of these episodic events is difficult. To address this question, we intend to contextualize the latest discoveries on the island's environmental reconstructions with what we know, from a regional perspective, of the principal geohazards that could have affected this remote enclave.

\subsection{Tracking the regional volcanic signal}

Studies of the sediments on the island present a chronology precise enough to permit a detailed analysis of the last 1000 years. The RAR-08 core of lacustrine sediments from Rano Raraku (Cañellas-Boltà, et al., 2013) and the ARO 08-02 core of peat from the Rano Aroi mire (Margalef et al., 2013; Rull et al., 2015) are some examples. Direct effects of the eruptions described in Section 2 are not feasible due to the enormous distance from the emitting focus. We may, however, be able to recognize indirect 
impacts on Easter Island, because these Pacific eruptions left important imprints on civilizations as distant as those in Europe.

The sequences the RAR-08 core depict an important magnetic susceptibility peak circa AD1280, which could be interpreted as an important entrance of detritic material to the center of the wetland basin. Similar processes in former times have been associated with episodes of higher precipitation (Sáez et al., 2009). The age of this intense pluvial event and the associated age uncertainty of this core section ( \pm 29 years) allow correlation with the Samalas eruption and its global impact. This correlation would be consistent with the studies demonstrating that tropical and intense eruptions can be precursors of changes to storm frequency and rain patterns and that ENSO intensity abruptly increased after the Samalas eruption (Rein et al., 2004, Cole Dai et al., 2009). The definitive attribution of this terrigenous peak to the consequences of the Samalas eruption can nevertheless only be achieved by more radiocarbon dating to reduce the present uncertainties of the chronological model.

The Rano Raraku sedimentary record also indicates that the deforestation around the lake started much earlier than what has been traditionally established (Cañellas-Boltà et al, 2013), with a strong intensification circa AD1200 culminating around AD1450. Documented evidence suggests that agricultural activity continued until AD1320 and 1440 (Horrocks et al., 2012). The $1250-1350$ period and the initial phase of the LIA are characterized in the Raraku basin by a decrease in palm abundance and a gradual increase in herbaceous species such as Poaceae and Verbena litoralis, together with an increase in charcoal remains (Cañellas-Boltà, 2013). Focusing on a narrower temporal scale, however, indicates coherent fluctuations between the vegetal cover and the occurrence of the AD1257 Samalas and the AD1450 Kuwae volcanic eruptions. The main tendencies of the vegetal cover in this period were interrupted by two changes in 
the relative abundance of pollen taxa, with less Poaceae and Palmae pollen and more $V$. litoralis pollen. The abundance of wetland taxa (Cyperaceae) also decreased, a detriment coinciding with the higher entrance of clastic material (Figure 2). Heavy rains suggested by the magnetic susceptibility could have limited the expansion of the shore vegetation and floating mats by the arrival of large detritic inputs. The Rano Aroi basin on the highest part of the island evolved differently. Rull et al. (2016) described a change in the pollen zones around 1250, apparently driven by natural causes, because human activity had not prevailed in the area at that time. The deforestation around Rano Aroi began in 1550 and ended in 1650, but the area was likely occupied only by marginal populations (Rull, 2016). On the other hand, Horrocks et al. (2015) suggests a period of deforestation between 1240 and 1610 AD. The authors conclude that Rano Aroi was occupied after $1670 \mathrm{CE}$, later and shorter than at lowland sites, which is consistent with Rull et al. (2015) proposal.

The premise that the available sedimentary records for Easter Island have captured indirect impacts of the main global eruptions from the past cannot be rejected. These vegetal changes were synchronous with regional cooling and lower sea levels (Nunn, 2000) (Figure 2). Periods in which the intertropical convergence zone migrated southward (Haug et al., 1999) and cyclones were more frequent (Toomey et al., 2013) have been described in areas under the influence of the South Pacific convergence zone (Margalef et al., 2014). The nature and resolution of our Easter Island evidence, however, do not infer causality from chronological correlations with regional observations. Whether or not Rapa Nui's ecological and cultural changes are a consequence of these main eruptions cannot be fully addressed with the available evidence and will require further multidisciplinary research. The geochemical and 
chronological study of coral growth could contribute to this open question. Interest in the growth of coral has also been expressed in a recent review (Rull, 2016).

\subsection{Easter Island and the risk of tsunamis}

Easter Island is $3500 \mathrm{~km}$ from South America and therefore vulnerable to tsunamis generated on the circum-Pacific subduction zones, especially those in South America. In the last century, Rapa Nui was affected by tsunamis generated in the Alaska trench in 1946 (Okal et al., 2002) and along the coast of Chile in 1960 and 2010 (Fritz et al., 2011). The $M_{W} 8.1$ event in Chile in 1995 generated a flood of decimeters (Guibourg et al., 1997). The last demonstration of the vulnerability of Easter Island to tsunamis from distant sources was on 16 September 2015, when a tsunami reached the island after the Illapel-Coquimbo earthquake $\left(\mathrm{M}_{\mathrm{W}} 8.4\right.$ magnitude). Local witnesses reported some damage to old stone walls near the coast.

Waves at least $6 \mathrm{~m}$ high arrived to the island during the largest tsunami documented, after the 1960 Valdivia earthquake ( $\mathrm{M}_{\mathrm{W}} 9.5$ magnitude). Despite island's topography provides an effective protection, the Tongariki ahu platform was completely flooded (SHOA, 2000), and 50-t moais were moved more than $60 \mathrm{~m}$ inland (Domínguez, 1961). Photographs from a few days before and after the tsunami were taken by Lorenzo Domínguez, a Chilean artist (Figure 3).

Recent reviews show how dated archeological evidences (Mulrooney, 2013) and the vast majority of hare paenga (boat-shaped house) distribution (Thomas, 2014) suggest that human activity during the last millennia mostly occurred in coastal areas. Inland landscapes where mainly occupied for agricultural purposes (Puleston et al., 2017) although some later residences were also established. 
To estimate the frequency of tsunamis that could affect Easter Island in past times, we simulated a series of tsunamis and conducted a seismotectonic analysis. Not all Pacific subduction zones have the capacity to generate tsunamis that could endanger Easter Island due to the direction of the waves generated by tsunamis, the maximum wave heights perpendicular to the generating source and the dissipation of energy with distance (see for example Kajiura, 1970). The subduction zones with the greatest potential to produce damaging tsunamis at Easter island are: Tonga-Kermadec, Marianas, Japan, Alaska, Mexico, Central America, Peru and Chile (red in Figure 4). We developed a number of tsunami simulations using COMCOT (Liu et al., 1995) to obtain the wave propagation taking into account the circum Pacific subduction characteristics (Berryman et al., 2015) and estimated the tsunami inundation in our models using the Synolakis (1987) formulation for comparing our results to observed run-ups.

Our numerical model was based on the linear shallow-water equations resolved on a scheme of finite difference with three nested grids with increasing resolutions of $10^{\prime}, 2^{\prime}$ and 30". We simulated the 1946 Alaskan earthquake (Okal et al., 2007) and the 1960 (Barrientos and Ward, 1990) and 2010 (Lorito et al., 2011) Chilean earthquakes as control. For the Chilean earthquakes, the run-ups at Hanga Roa were $2.7 \mathrm{~m}$ for the $\mathrm{M}_{\mathrm{W}}$ 8.82010 earthquake and $>6 \mathrm{~m}$ for the $\mathrm{M}_{\mathrm{W}} 9.51960$ earthquake, and our simulations produced run-ups of 2.8 and $6.8 \mathrm{~m}$, respectively, correlating well with the observations. Our estimated run-up for the 1946 Alaskan earthquake was not conclusive (1.4 m vs the observed $8.6 \mathrm{~m}$, Okal et al., 2002), perhaps due to the large uncertainties about the tsunami source, because a submarine landslide or complex ruptures were also probably involved. Our results were nevertheless consistent with the Alaskan subduction; the $1964 \mathrm{M}_{\mathrm{W}}$ 9.2 Alaskan earthquake in Prince William Sound, which produced tsunami 
run-ups of several meters in Hawaii, did not damage Easter Island, as our results showed.

We modeled worst-case scenarios and a $M_{W} 8.5$ magnitude event for each of the subduction zones mentioned above (the source dimensions for the events were modeled in agreement with Berryman et al. (2015)). The propagation of a tsunami wave can be considered a linear phenomenon in deep water, so we can obtain a correlation between the estimated run-up height and the corresponding earthquake magnitude. We can then establish the minimum earthquake magnitude needed to produce tsunamis that could damage Easter island for each circum-Pacific subduction segment.

The period of recurrence for an earthquake magnitude in each subduction zone can be expressed as:

$\lambda_{\mathrm{Mi}}=\exp \left(\alpha-\beta_{\mathrm{Mi}}\right)$

where $\alpha=\mathrm{a} \times \ln (10), \beta=\mathrm{b} \times \ln (10)$ and $\mathrm{a}$ and $\mathrm{b}$ are the parameters of the GutenbergRichter law. The recurrent period is defined as the inverse of the annual rate of exceedance: $\mathrm{T}=1 / \lambda_{\mathrm{Mi}}$. We used the values of "b" estimated by Berryman et al., 2015. The values of "a" are obtained from the worst case event average slip and plate subduction velocity calculated as:

$\mathrm{a}=\left(\ln 1 / \mathrm{T}_{\max }+\beta_{\mathrm{Mmax}}\right) / \ln (10)$

The recurrent period on Easter Island of tsunamis generated by earthquakes, $\mathrm{T}_{\mathrm{EI}}$, is analogous to $1 / \lambda_{\mathrm{EI}}$ :

$\lambda_{E I}=\sum_{1}^{n s u b} \lambda_{M_{\text {min }}, n s u b}$

(Eq. 3) 
Our results indicated that events similar to the Chilean 2010 tsunami could reach Easter Island every 15-20 years, mainly from Chile but also from Peru, Mexico, Japan and Tonga-Kermadec. More devastating tsunamis, generated mainly in South America, such as the 1960 Chilean tsunami, had recurrent periods of 50-60 years, in agreement with the results of Nakamura (1986) for the Eastern Pacific.

At least 50 tsunamis may have reached Easter Island during the last 1000 years, including high magnitude events, such as the 1960 earthquake or the 1575 earthquake in southern Chile (Goff et al., 2011b), but also others such as the 1604 earthquake in northern Chile (Goff et al., 2010c) or the 1586, 1409 and 1449 earthquakes in Peru (Vargas et al., 2005; Bilek, 2009). No signs of these potential tsunamis have yet been found in archeological settings or lacustrine records, the latter due to the isolation from the sea of the Raraku and Aroi sites at the bottoms of volcano craters. Identification of tsunamigenic sedimentological features in transitional marine-terrestrial environments requires a challenging and interdisciplinary approach (Scheffers and Kelletat, 2003, Rubin et al., 2017), which has not yet been developed for the island and would need to be taken into account in future projections.

\section{CONCLUSIONS}

The Pacific Basin is the main region of volcanic activity, earthquakes and tsunamis, but the impact of these high-energy events have traditionally been overlooked as drivers of environmental and cultural changes in the reconstruction of PIC history. This oversight may be due to the difficulty of recognizing their imprints in the records and landscapes but also to the difficulty of dating the events with sufficient accuracy.

No direct effects of the main eruptions of the last millennia (AD1257 and 1453) have yet been identified on Easter Island. Records for Rano Raraku and Rano Aroi, however, 
may eventually identify indirect effects of these volcanic episodes by changes to the regional climate, e.g. temperature, but also to changes in sea level, ENSO dynamics and the cultures that have been described across the Pacific Basin. The likelihood of destructive tsunamis hitting the island during the last millennia has been demonstrated, with an estimated recurrence period for large events of less than a century. This estimate is a new insight that needs to be taken into account when analyzing Rapa Nui cultural history and archeological sites, especially those at the more vulnerable coastal locations.

The reconstruction of the histories of ancient Pacific societies is an extraordinarily complex exercise due to the lack of written chronicles and the evident fragmentation of the large territory. This endeavor has made outstanding advances during the last 20 years despite these difficulties. Several enigmas, however, remain, despite several satisfactory attempts to provide regional correlations (Nunn, 2007). The nature and reach of the $1250-1350$ period, at a time with many climatic, environmental and cultural changes, or the reasons for the sudden stop in trade among distant islands around 1450, though, have not yet been clarified. The geohazards mentioned above (volcanoes and tsunamis) may have contributed to these unsolved questions, but further research is needed for clarification.

New records with better resolution and an efficient integration of the existing data that comprise the landscape and cultural changes of the last millennia are required to determine the impact of past high-energy events on PICs. The currently available data are very diverse in theme and format, which complicates their collection and correlation. An open-access database for Pacific Island records for the sharing of data of different natures would be very useful to the scientific community. The first steps have been provided for Easter Island by the radiocarbon databases from archeological sites (Mulrooney, 2013) and by sedimentary records (Rull, 2016b). An online, accessible 
Pacific Island database practically and simply organized would facilitate real interactive synergies for coordinating the frontiers of present knowledge.

\title{
References
}

Allen M 2006 New ideas about late Holocene climate variability in the central Pacific Current Anthropology, 47(3), 521-535

Anderson A 2009 Epilogue: Changing Archaeological Perspectives upon Historical Ecology in the Pacific Islands 1 Pacific Science, 63(4), 747-757

\begin{abstract}
Aswani S, Allen MS 2009 Marquesan coral reef (French Polynesia) in historical context: an integrated socio-ecological approach Aquatic Conservation: Marine and Freshwater Ecosystems 19, 614-625
\end{abstract}

Bahn P, Flenley J 1992 Easter Island, Earth Island Thames and Hudson, London

Barrientos S E, Ward S N 1990 The 1960 Chile earthquake: inversion for slip distribution from surface deformation Geophysical Journal International, 103(3), 589598

Bayliss-Smith, Golson and Hughes 2107, in J. Golson, T. Denham, P.J. Hughes and P. Swadling, eds. 'Ten Thousand years of Cultivation: Kuk Swamp and the History of Agriculture in the Papua New Guinea Highlands'. Terra Australis monographs, ANU Press, Canberra

\author{
Berryman K, Wallace L, Hayes G, Bird P, Wang K, Basili R, Lay T, Pagani M, \\ Stein RS, Sagiya T, Rubin A M, Barrientos S, Kreemer C, Litchfield N, Stirling M, \\ Gledhill K, Haller K, Costa C 2015. The GEM Faulted Earth Subduction \\ Characterisation Project (Version 2.0).
}


Bilek S L 2009 Seismicity along the South American subduction zone: review of large earthquakes, tsunamis, and subduction zone complexity Tectonophysics 495, 2-14

Blong R, Fallon S, Wood R, McKee C, Chen K, Magill C, Barter P 2017.

Significance and timing of the mid-17th-century eruption of Long Island, Papua New Guinea. The Holocene, 0959683617735589.

Cañellas-Boltà N, Rull V, Sáez A, Margalef O, Bao R, Pla-Rabes S, Giralt S (2013). Vegetation changes and human settlement of Easter Island during the last millennia: a multiproxy study of the Lake Raraku sediments. Quaternary Science Reviews, 72, 3648.

\title{
Cañellas-Boltà N, Rull V, Sáez A, Margalef O, Pla-Rabes S, Valero-Garcés B L,
}

Giralt S 2016 Vegetation dynamics at Raraku Lake catchment (Easter Island) during the past 34,000 years Palaeogeography, Palaeoclimatology, Palaeoecology, 446, 55-69

\begin{abstract}
Castellano E, Becagli S, Hansson M, Hutterli M, Petit J R, Rampino M R, Severi M, Steffensen J P, Traversi R, Udisti R 2005 Holocene volcanic history as recorded in the sulfate stratigraphy of the European Project for Ice Coring in Antarctica Dome C (EDC96) ice core Journal of Geophysical Research: Atmospheres, 110(D6)
\end{abstract}

\author{
Chagué-Goff C, Goff J, Nichol S, Dudley W, Zawadzki A, Bennett J, Mooney S \\ , Fierro D , Heijnis H, Dominey-Howes D , Courtney C 2012 Multi-proxy evidence \\ for trans-Pacific tsunamis in the Hawai'ian Islands Mar. Geol. 299-302, 77-89
}


Cole-Dai J, Ferris D, Lanciki A, Savarino J, Baroni M, Thiemens M H 2009 Cold decade (AD 1810-1819) caused by Tambora (1815) and another (1809) stratospheric volcanic eruption Geophysical Research Letters, 36(22)

Deirmendjian D 1973 On volcanic and other particulate turbidity anomalies Advances in Geophysics, 16: 267-296

Domínguez L 1961 Diario de la Isla de Pascua Catálogo General Copyright (C) 1963-2017 by The Estate of Lorenzo Dominguez Accessed from www

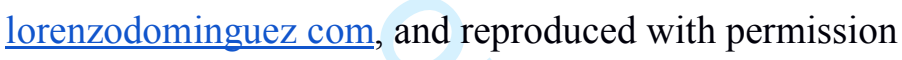

Emile-Geay J, Seager R, Cane M A, Cook E R, Haug G H (2008) Volcanoes and ENSO over the past millennium Journal of Climate, 21(13), 3134-3148

Fritz H M, Petroff C M, Catalán P A, Cienfuegos R, Winckler P, Kalligeris N, Weiss R, Barrientos S E, Meneses G, Valderas-Bermejo C, Ebeling C, Papadopoulos A, Contreras M, Almar R, Dominguez J C, Synolakis C E 2011 Field Survey of the 27 February 2010 Chile Tsunami Pure and Applied Geophysics, 168(11): 1989-2010

Frohlich C, Hornbach M J, Taylor F W, Shen C C, Moala A, Morton A E, Kruger

J 2009 Huge erratic boulders in Tonga deposited by a prehistoric tsunami Geology, $37(2), 131-134$

Guibourg S, Heinrich P, Roche R 1997 Numerical modeling of the 1995 Chilean Tsunami Impact on French Polynesia Geophysical Research Letters, 24(7): 775-778

Gill W W 1916 Extracts from Dr Wyatt Gill's papers Journal of the Polynesian Society, 20, 116-151 
Goff J R, Pearce S, Nichol S L, Chagué-Goff C, Horrocks M, Strotz L 2010

Multiproxy records of regionally-sourced tsunamis, New Zealand Geomorphology 118, $369-382$

Goff J, Chagué-Goff C, Dominey-Howes D, McAdoo B, Cronin S, Bonté-Grapetin M, Nichol S, Horrocks M, Cisternas M, Lamarche G, Pelletier B, Jaffe B, Dudley

W 2011a Palaeotsunamis in the Pacific Islands Earth-Science Reviews, 107(1), 141

Goff J, Lamarche G, Pelletier B 2011b Palaeotsunami precursors to the 2009 South Pacific tsunami in the Wallis and Futuna archipelago Earth-Science Reviews 107: 91106

Goff J, McFadgen B G, Chagué-Goff C, Nichol S L 2012 Palaeotsunamis and their influence on Polynesian settlement The Holocene, 22(9), 1067-1069

Hansen J, Sato M, Ruedy R, Lacis A, Asamoah K, Borenstein S, Brown E, Cairns B, Caliri G, Campbell M, Curran B, deCastro S, Druyan L, Fox M, Johnson C, Lerner J, McCormick M, Miller R, Minnis P, Morrison A, Pandolfo L, Ramberrann I, Zaucker F, Robinson M, Russel P, Shah K, Stone P, Tegen I, Thomason L, Wilder J, Wilson H J 1996 A Pinatubo climate modeling investigation In The Mount Pinatubo Eruption (pp 233-272) Springer Berlin Heidelberg

\author{
Haug G H, Hughen K A, Sigman D M, Peterson L C, Röhl U 2001 Southward \\ migration of the intertropical convergence zone through the Holocene Science, \\ 293(5533), 1304-1308
}


Hoffmann, G., Silver, E., \& Day, S. 2008. Volcanic flow deposits on the flanks of Long Island, Papua New Guinea: lavas or pyroclastics?. In AGU Fall Meeting Abstracts.

\author{
Horrocks M, Baisden W T, Flenley J, Feek D, Gonzalez-Nualart L, Haoa-Cardinali \\ S, Edmunds-Gorman T 2012 Fossil plant remains at Rano Raraku, Easter Island's \\ statue quarry: evidence for past elevated lake level and ancient Polynesian agriculture $\mathrm{J}$ \\ Paleolimnol 46, 767-783
}

Hunter-Anderson R L 1998 Human vs climatic impacts at Easter Island: did the people really cut down all those trees? In: Stevenson, C M , Lee, G, Morin, F J (Eds ), Easter Island in Pacific Context Proceedings of the Fourth International Conference on Easter Island and East Polynesia The Easter Island Foundation, Los Osos, pp 85e99

Kajiura K 1970 Tsunami Source, Energy and the Directivity of Wave Radiation Bulletin of the Earthquake Research Institute, 48: 835-869

\author{
Lavigne F, Degeai J P, Komorowski, J C, Guillet S, Robert V, Lahitte P, \\ Oppenheimer C, Stoffel M, Vidal C M, Surono, Pratomo I, Wassmer P, Hajdas I, \\ Hadmoko D S, Belizal E 2013 Source of the great AD 1257 mystery eruption \\ unveiled, Samalas volcano, Rinjani Volcanic Complex, Indonesia Proceedings of the \\ National Academy of Sciences, 110(42), 16742-16747
}

LeGrande A N and Anchukaitis K J 2015 Volcanic eruptions and climate PAGES Newsletter, 23, 46-47

Lipo C P, Hunt T L, Horneman R, Bonhomme V (2016) Weapons of war? Rapa Nui mata'a morphometric analyses Antiquity, 90(349), 172-187 
Liu P L F, Cho Y S, Briggs M J, Kanoglu U, Synolakis C E 1995 Runup of solitary waves on a circular island Journal of Fluid Mechanics, 302, 259-285

Lorito S, Romano F, Atzori S, Tong X, Avallone A, McCloskey J, Cocco M, Boschi E, Piatanesi A 2011 Limited overlap between the seismic gap and coseismic slip of the great 2010 Chile earthquake Nature Geoscience, 4(3): 173-177

Lowe D J and de Lange W P 2000 Volcano-meteorological tsunamis, thec AD 200 Taupo eruption (New Zealand) and the possibility of a global tsunami The Holocene, 10(3), 401-407

Margalef O, Cañellas-Boltà N, Pla-Rabes S, Giralt S, Pueyo J J, Joosten H, Rull V, Buchaca T, Hernández A, Valero-Garcés B L, Moreno, A, Sáez A

2013 A 70,000 year multiproxy record of climatic and environmental change from Rano Aroi peatland (Easter Island) Global and Planetary Change, 108, 72-84

Mayewski P A, Rohling E E, Stager J C, Karlén W, Maasch K A, Meeker L D, Meyerson E A, Gasse F, van Kreveld S, Holmgren, K, Lee-Thorp J, Rosqvist G, Rack F, Staubwasser M, Schneider R, Lee-Thorp J 2004 Holocene climate variability. Quaternary research, 62(3), 243-255.

McCormick M, Veiga R E 1992 SAGE II measurements of early Pinatubo aerosols Geophysical Research Letters, 19(2), 155-158

McFadgen BG 2007 Hostile Shores - Catastrophic Events in Prehistoric New Zealand and their Impact on Maori Coastal Communities Auckland: Auckland University Press 
Garbe-Schoenberg D, Watts P 2004 Megatsunami deposits on Kohala volcano, Hawaii, from flank collapse of Mauna Loa. Geology 32 (9), 741-744.

\author{
Miller G H, Geirsdóttir Á, Zhong Y, Larsen D J, Otto-Bliesner B L, Holland M \\ M, Anderson C 2012 Abrupt onset of the Little Ice Age triggered by volcanism and \\ sustained by sea-ice/ocean feedbacks Geophysical Research Letters, 39(2)
}

Mulrooney M, 2013 An island-wide assessment of the chronology of settlement and land use on RapaNui (Easter Island) based on radiocarbon data J Archaeol Sci 40, $4377 \mathrm{e} 4399$

Nakamura S. 1986. Estimate of exceedance probability of tsunami occurrence in the eastern pacific. Marine Geodesy, 10(2), 195-209.

\begin{abstract}
Newhall C G, Self S 1982 The volcanic explosivity index (VEI) an estimate of explosive magnitude for historical volcanism Journal of Geophysical Research: Oceans, 87(C2), 1231-1238 Nunn, P D 2000 Environmental catastrophe in the Pacific Islands around A D 1300 Geoarchaeology, 15: 715-740
\end{abstract}

Noormets R, Felton E, Crook K A 2002 Sedimentology of rocky shorelines: 2: shoreline megaclasts on the north shore of Oahu, Hawaii — origins and history. Sediment. Geol. 150 (1-2), 31-45.

Nunn P D 2000 Environmental catastrophe in the Pacific Islands around A D 1300 Geoarchaeology, 15(7), 715-740 


\begin{abstract}
Nunn P D 2007 Climate, Environment and Society in the Pacific During the Last Millennium Elsevier, Amsterdam
\end{abstract}

\begin{abstract}
Nunn P D, Hunter-Anderson R, Carson M T, Thomas F, Ulm S, Rowland, M J 2007 Times of plenty, times of less: last-millennium societal disruption in the Pacific Basin Human Ecology, 35(4), 385-401
\end{abstract}

\begin{abstract}
Nunn P D, and Pastorizo R 2007 Geological histories and geohazard potential of Pacific Islands illuminated by myths Geological Society, London, Special Publications, 273(1), 143-163
\end{abstract}
Nunn P D and Peltier W R 2001 Far-field test of the ICE-4G model of global isostatic response to deglaciation using empirical and theoretical Holocene sea-level reconstructions for the Fiji Islands, southwestern Pacific Quaternary Research, 55(2), 203-214

Okal E A, Synolakis C E, Fryer G J, Heinrich P, Borrero J C, Ruscher C, Arcas D, Guille G, Rousseau D 2002 A Field Survey of the 1946 Aleutian Tsunami in the Far Field Seismological Research Letters, 73(4), 490-503

Okal E A and Hebert H 2007 Far-field simulation of the 1946 Aleutian tsunami Geophysical Journal International, 169: 1229-1238

Oppenheimer, C 2003 Climatic, environmental and human consequences of the largest known historic eruption: Tambora volcano (Indonesia) 1815 Progress in physical geography, 27(2), 230-259 


\title{
Paris R, Wassmer P, Lavigne F, Belousov A, Belousova M, Iskandarsyah Y, \\ Benbakkar M, Ontowirjo B, Mazzoni N 2014 Coupling eruption and tsunami records: the Krakatau 1883 case study, Indonesia Bulletin of Volcanology, 76(4), 814 \\ Pérez-Torrado F J, Paris R, Cabrera M C, Schneider J L, Wassmer P, Carracedo J \\ C, Rodríguez-Santana Á, Santana, F 2006 Tsunami deposits related to flank collapse in oceanic volcanoes: the Agaete Valley evidence, Gran Canaria, Canary Islands. Mar.
} Geol. 227 (1), 135-149.

Puleston C O, Ladefoged T N, Haoa S, Chadwick O A, Vitousek P M, Stevenson, C 2017 Rain, Sun, Soil, and Sweat: A Consideration of Population Limits on Rapa Nui (Easter Island) before European Contact. Frontiers in Ecology and Evolution, 5, 69.

\author{
Ramalho R S, Quartau R, Trenhaile A S, Mitchell N C, Woodroffe C D, Ávila . P \\ 2013 Coastal evolution on volcanic oceanic islands: A complex interplay between \\ volcanism, erosion, sedimentation, sea-level change and biogenic production. Earth- \\ Science Reviews, 127, 140-170.
}

Rein B, Lückge A, Sirocko F 2004 A major Holocene ENSO anomaly during the Medieval period Geophysical Research Letters, 31(17)

\author{
Rubin C, Horton B, Sieh, K, Pilarczyk J, Daly P, Ismail N, Parnell A 2017 Highly \\ variable recurrence of tsunamis in the 7,400 years before the 2004 Indian Ocean \\ tsunami Nature communications, 8, 16019
}




\begin{abstract}
Rull V, Cañellas-Boltà N, Margalef O, Sáez A, Pla-Rabes S, Giralt S 2015 Late
Holocene vegetation dynamics and deforestation in Rano Aroi: implications for Easter Island's ecological and cultural history Quaternary Science Reviews, 126, 219-226
\end{abstract}

Rull V 2016a Natural and anthropogenic drivers of cultural change on Easter Island: Review and new insights Quaternary Science Reviews, 150, 31-41

Rull V 2016b The EIRA database: Glacial to Holocene radiocarbon ages from Easter Island's sedimentary records Frontiers in Ecology and Evolution, 4

\author{
Rull V, Cañellas-Boltà N, Margalef O, Pla-Rabes S, Sáez, Giralt S 2016 Three \\ millennia of climatic, ecological, and cultural change on Easter Island: an integrative \\ overview Frontiers in Ecology and Evolution, 4, 29
}

\author{
Sáez A, Valero-Garces B, Giralt S, Moreno A, Bao R, Pueyo J J, Casas D 2009 \\ Glacial to Holocene climate changes in the SE Pacific The Raraku lake sedimentary \\ record (Easter Island, 27 S) Quaternary Science Reviews, 28(25), 2743-2759
}

Schoeberl M, Bhartia P, Hilsenrath E, Torres O 1993 Tropical ozone loss following the eruption of Mt Pinatubo Geophysical research letters, 20(1), 29-32

Self S and Rampino M 1981 The 1883 eruption of Krakatau Nature, 294: 699- 704

Self S, Gertisser R, Thordarson T, Rampino M, Wolff J 2004 Magma volume, volatile emissions, and stratospheric aerosols from the 1815 eruption of Tambora Geophysical Research Letters, 31(20) 
Scheffers A and Kelletat D 2003 Sedimentologic and geomorphologic tsunami imprints worldwide - a review Earth-Science Reviews, 63(1), 83-92

SHOA 2000 El maremoto del 22 mayo de 1960 en las costas de Chile Servicio Hidrográfico y Oceanográfico de la Armada de Chile, 2a Edición, Santiago, Chile

Simkin T, Fiske R 1983 Krakatau 1883: The volcanic eruption and its effects Smithsonian Institution Press, Washington, DC

Sinoto Y 1979 Excavations on Huahine, French Polynesia Pacific Studies III: 1-40

Synolakis C 1987 The runup of solitary waves Journal of Fluid Mechanics, 185: 523545

Toomey M, Donnelly J, and Woodruff J 2013 Reconstructing mid-late Holocene cyclone variability in the Central Pacific using sedimentary records from Tahaa, French Polynesia Quaternary Science Reviews, 77, 181-189

Vargas G, Ortlieb L, Chapron E, Valdes J, Marquard C 2005 Paleoseismic inferences from a high-resolution marine sedimentary record in northern Chile $\left(23^{\circ} \mathrm{S}\right)$ Tectonophysics 399, 381-398

Vidal C, Komorowski J, Métrich N, Pratomo I, Kartadinata N, Prambada O, Michel A, Carazzo G, Lavigne F, Rodysill J, Fontijn K, Surono 2015 Dynamics of the major plinian eruption of Samalas in 1257 AD (Lombok, Indonesia) Bulletin of Volcanology, 77(9), 73 
Weisler, M 1995 Henderson Island prehistory: colonization and extinction on a remote Polynesian island Biological Journal of the Linnean Society, 56(1-2), 377-404

Weisler M 2002 Centrality and the collapse of long-distance voyaging in East Polynesia Geochemical Evidence for Long-Distance Exchange, Bergin and Garvey, London, 257-273

Woodroffe, C.D., 2008. Reef-island topography and the vulnerability of atolls to sealevel rise. Glob. Planet. Chang. 62 (1), 77-96.

\section{Acknowledgements}

This research was funded thanks to the projects through the projects LAVOLTER (CGL2004-00683/BTE) and GEOBILA (CGL2007-60932/BTE). We want to thank to the family of Lorenzo Dominguez the permission to reproduce the pictures from the artist. We also want to acknowledge the CartoGIS tool from ANU College of Asia and the Pacific (Australian National University) as the copyleft source of the map of the Pacific (Figure 1). 


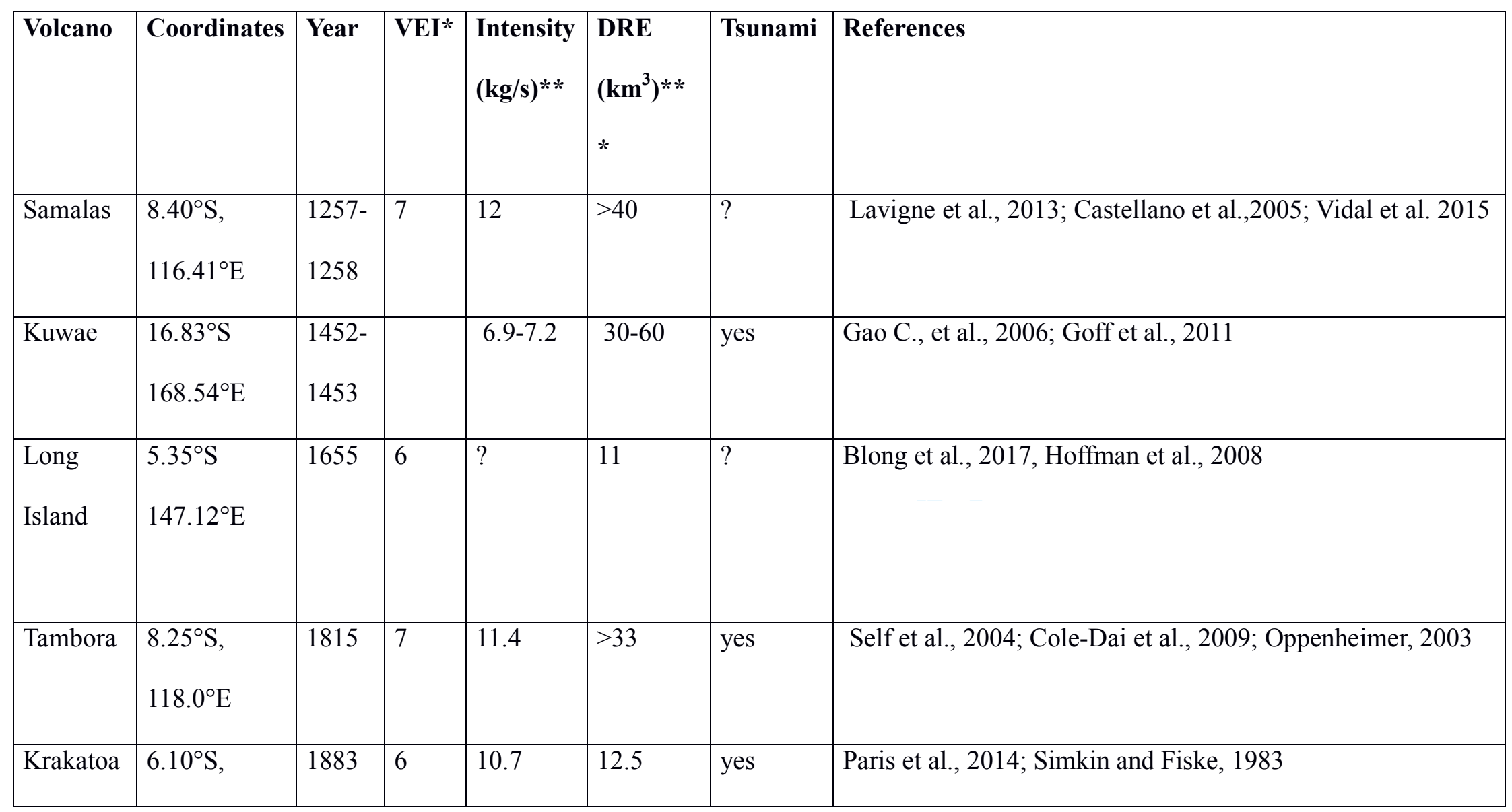




\begin{tabular}{|l|l|l|l|l|l|l|l|}
\hline & $105.41^{\circ} \mathrm{E}$ & & & & & & \\
\hline Pinatubo & $15.13^{\circ} \mathrm{N}$, & 1991 & 6 & 11.6 & 5 & $?$ & Hansen et al., 1996; Schoeberl et al., 1993 \\
& $120.35^{\circ} \mathrm{E}$ & & & & & & \\
\hline
\end{tabular}

Table 1. Details of the main circumPacific south Hemisphere volcanic eruptions of the last millennia. *VEI, volcanic explosivity index, is a relative measure of the explosiveness of volcanic eruptions from 0 to $8 .{ }^{* *}$ Intensity is the rate of mass eruption in $\mathrm{kg} / \mathrm{s} .{ }^{* * *} \mathrm{DRE}, \mathrm{dense-rock}$ equivalent, is an estimate of the volume of magma emitted during the volcanic eruption. 
2

3

4

5

6

7

8

10

11

12

13

14

15

16

17

18

19

20

21

22

23

24

26

27

28

29

30

31

32

33

34

35

36

37

39

40

41

42

43

44

45

46

47

48

49

50

51

52

53

54

55

56

57

58

59

60 


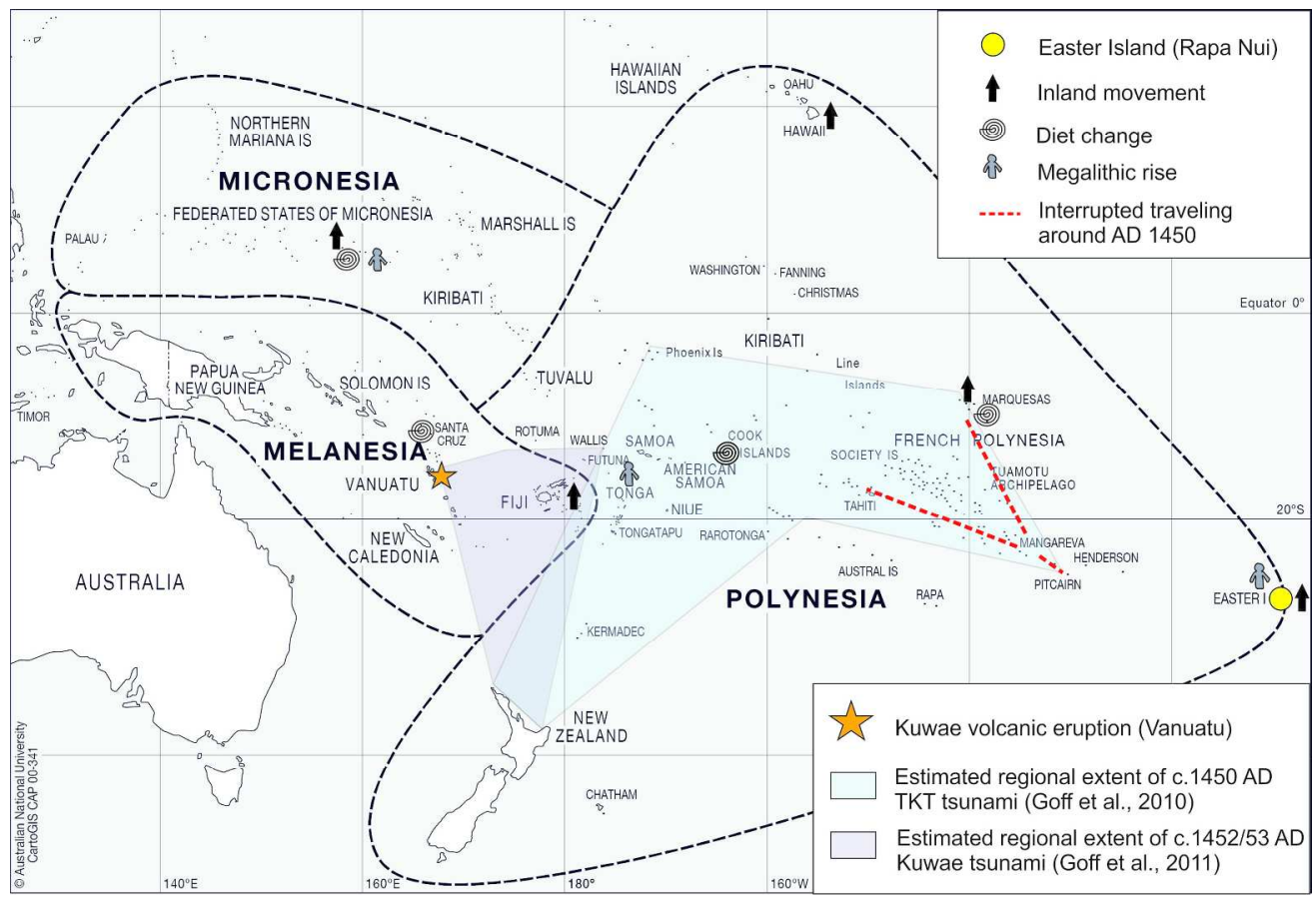

Figure 1. Map of the Pacific Ocean islands. Easter Island is at the easternmost edge of Polynesia. Main cultural changes recorded during the 1300 event and the Little Ace Age are detailed, together with the effect of the ENSO phases on precipitation and the deduced reach of the 1450 Tonga-Kermadec (TKT) and 1452 Kuwae tsunamis. 
Figure 2. Summary of the main climatic trends in the Pacific Ocean between AD 800 and AD 1800 (Nunn, 2000; Haug et al., 2001; Toomey er al., 2013) and a record of trade among islands from Henderson Island (Weisler, 1995). The main pollen taxa from Rano Raraku (Cañellas-Boltà, 2013) for the same period and the main landscape phases recorded in Rano Aroi (Rull et al., 2015) are also included.

$691 \times 297 \mathrm{~mm}(300 \times 300 \mathrm{DPI})$ 
Figure 3. Images before $(A, B, C)$ and after $(D, E)$ the Valdivia earthquake. The 50 -t moais were transported $60 \mathrm{~m}$ inland. Several stone walls at the base of Raraku crater were completely ruined, exposing several human bones (E). 


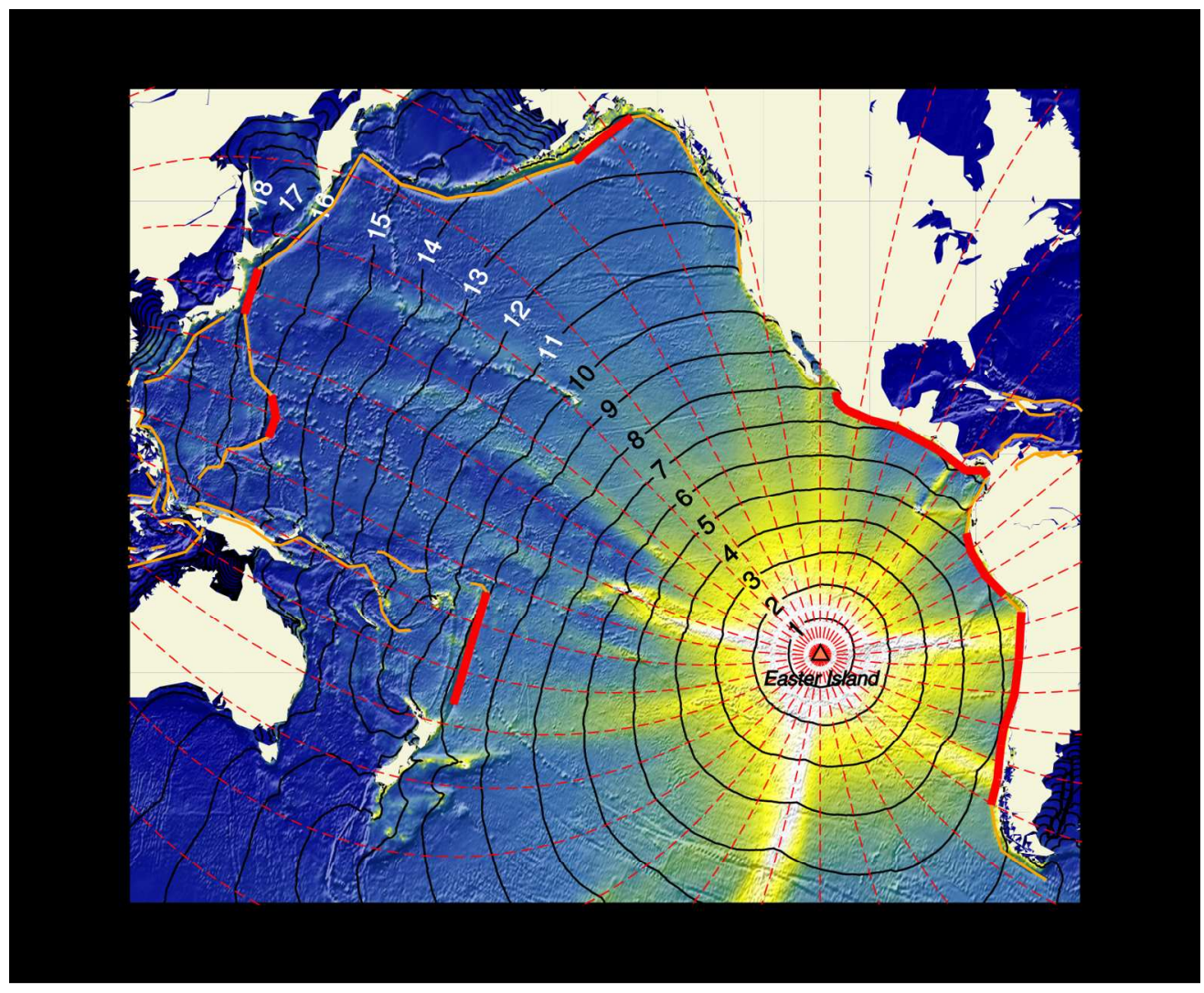

Figure 4. Inverse tsunami-propagation map for Easter Island. The color intensity indicates the attenuation of tsunami wave height; the brighter the color, the higher the waves. The isolines show reverse tsunami travel times in hours, e.g. a tsunami generated in Tonga-Kermadec would reach Easter Island in $9 \mathrm{~h}$. The subduction segments with greater capacities to generate tsunamis for Easter Island are marked in red. Red dashed lines indicate rectilinear trajectories from Easter Island. 